\title{
Research of the Features of The Electricity Market
}

\author{
Mansur Hamitovich Gazeev
}

Elena Marsovna Deberdieva

Sergei Stanislavovich Chuhlantsev

Tyumen State Oil and Gas University, Tyumen, Russian Federation

Nataliia Aleksandrovna Volynskaya

Fuel and Energy Independent Institute, Moscow, Russian Federation

Doi:10.5901/mjss.2015.v6n4s4p190

\author{
Email: emd61067@inbox.ru
}

\section{Abstract}

The article describes features of the electricity market, determined by the specificity of the circulating product. It is shown that electricity as a specific product, which is characterized by the demand inelasticity, continuity of the production and consumption processes, impossibility of accumulation and storage, standardized product range, etc., determines the basic characteristics of the electricity (power and capacity) market. Herewith, capacity can be considered as a related product. The level of competition in the electricity market is largely dependent on the presence of restrictions in the choice of markets; differentiation of the products; choice of fuel resources and their suppliers. In addition, an essential condition for the electricity market operation is the availability of a related infrastructure. The main electricity market models are described, which have been practically implemented in the world: the markets, in which only electric power is sold, the markets with capacity turnover, and the markets differentiation depending on the model of their organization. A brief description of the structure of the domestic market of the countries demonstrating the successful experience of the electricity market operation is provided. At the same time, a distinctive feature of the current Russian electricity market is the incompleteness of its architecture, difficulties in ensuring its competitiveness due to the allocation of a minimum number of price zones, which are characterized by a large number of suppliers and purchasers of electricity, a developed grid infrastructure. In addition, the so-called non-price zones, in which the prevailing conditions hinder organizing a full-fledged market economy, are highlighted. The conclusion about the need for further study of the electricity market operation in different regions in order to make use of the positive experience is made.

Keywords: wholesale electricity market, market model, power generating company, manufacturer of electric power, competition, participants of the electricity market.

\section{Introduction}

The electricity market is quite a unique market due to a number of specific features: low elasticity of demand for electricity; specificity of competition because of the lack of product differentiation; limitation of the capacity of power grids; uneven consumption; and others. An analysis of the formation and development of the Russian electricity market, accompanying the process of transformation in the industry, allows systematizing its main features and peculiarities.

In spite of the inherent in the Russian electricity market features of a traditional electricity market, experts say that it has significant differences. In addition, some experts believe that construction of a classic electricity market is not reasonable in the Russian context. Having proven its "arm's length principle" and operability, the existing electricity market model still needs to be adjusted, because it does not fully take into account the changing realities of today.

This all points to the need and relevance of further study of the features of the electricity market operation and the practice of its functioning and regulation in different regions, which will subsequently allow formulating sound and effective corrective measures aimed at the development of a competitive market.

\section{Literature Review}

Various aspects of electricity and especially the functioning of the electricity market have repeatedly been addressed in the writings of scholars and practitioners, such as Barinov (2012), Gitel'man (2006, 2009, 2014), VanDoren (1998), Harris 
(2011), Averch and Johnson (1962), Pérez-Arriaga (2014), and others.

Researchers distinguish the following models of the electricity market, functioning in various countries: natural monopoly, retail competition, "single buyer," "exchange pool" (Hunt and Shuttleworth, 1996; Domah and Pollitt, 2001). Having investigated the electricity market from the natural monopoly position, Averch and Johnson concluded that government regulation has an ambiguous effect on the performance of the regulated entities and on the state of the industry market (Averch and Johnson, 1962). Tariff-based methods of regulation and the issues of technical assessment of the production and cost-efficiency performance of power utilities were approached by Balandin (2005).

Features of functioning of the Russian emerging market of electricity and capacity were approached by Andreev et al. (2013), Makarov (2007), Trachuk (2007), Kuznetsov et al. (1999), Aiuev (2008) who considered the conceptual principles of the capacity market, Belyaev and Podkovalnikova (2008) who studied the problems of the generating capacity development.

Generalization of international experience in the field of study was reflected in the works by Brovkina (2010), Eremin (2012), Kleiner (1999), Tukenov (2007, 2013), and others.

Our previous studies (Chukhlantsev, 2010) dedicated to the issues of management of electric power industry enterprises in the period of active restructuring reforms in the industry substantiated the necessity to create conditions for the effective functioning and development of the market participants, as well as the implementation of measures to ensure competition, improve pricing, and rationalize the capacity volumes.

\section{Methodology}

The study uses general scientific methods of systematic, logical, and comparative analysis, expert evaluations, hierarchy analysis, the retrospective, variation, and other research approaches.

Despite the relative diversity of electricity markets, a comparative analysis of them and the research results on this issue allow identifying four main models of organization of the electricity market: regulated monopoly; single buyer (only electricity producers compete with each other in the market); competition in the wholesale market (there are several producers and several buyers of electricity-distribution and retail companies; herewith, the latter exclusively distribute electricity to customers in the territory assigned to them); competition in the wholesale and retail markets (both producers and consumers of electricity freely compete with each other-the so-called "free" market) (Hunt and Shuttleworth, 1996; Balandin, 2005, Chukhlantsev, 2010, et al.). These models are characterized by consistent expansion of capabilities and areas of competition and can sequentially illustrate the transition from a monopoly to a liberalized electricity market.

Application of the comparative analysis has allowed identifying the common (for example, the product and the market participants) and specific, including country-related, features of the electricity market.

\section{Results}

\subsection{The revealed features of the electricity market.}

The features of any market are in the first place determined by the specific product represented on it. In the electricity market, the product has the following characteristic features: inelastic demand; continuity and coincidence of the processes of production and consumption; impossibility of accumulation and storage in large enough quantities; inability to address delivery of electricity and capacity from a specific manufacturer to a specific user; technological and infrastructural constraints in the supply of electric energy and capacity to consumers; a standardized range (Gitelman and Ratnikov, 2006).

Specific properties of electricity as a product, reflected in the fact that the processes of its production and consumption virtually coincide in time, result in a lack of or insufficient response of consumers to prices and, consequently, low elasticity of demand.

The high degree of homogeneity of electricity as a product determines the absence of brand or product differentiation in the classic sense. Only relative product differentiation at the stage of electricity generation (nuclear, hydro, heat, etc.) is possible, as well as the differentiation by the consumption modes (day or night, peak hours, etc.).

The factors that determine the specificity of the electricity market are the electricity generation technology, the uneven consumption and short duration of peak loads, which together with the duration of the investment cycle and the impossibility of storing electricity lead to the fact that there is a need for a separate sale of capacity.

In this regard, a special product on the market in question is capacity. The capacity market is designed to provide the required level of adequacy of the energy system through the acquisition of appropriate volume of the generating 
capacity. This suggests that buyers shall get the appropriate amount of capacity, and sellers shall provide it. Thus, capacity can be qualified as a product related to power. Sale of capacity allows power producers to obtain necessary means to ensure the reliable operation of the existing generating facilities and construction of new generation facilities and consumers of electricity - to plan ahead their investment, financial, and industrial activities in accordance with the obligations of suppliers. In addition, the guaranteed availability of a paid reserve of capacity minimizes the likelihood of a significant rise in prices during peak periods, as well as reduces the risk of interruptions in power supply.

Features of electric power and capacity as a product predetermine one more specific characteristic of the marketthe presence of a number of ancillary markets. This is due to the fact that for the operation of the power system, not only the parameters of the volume of electric power and capacity, but also a battery of additional parameters: capacity reserves for automatic regulation and stabilization of frequency, supply of reactive capacity to maintain voltage levels, availability of reserves for the start-up of a fully de-energized system in the event of blackouts, and so forth. Such services, in particular in the Russian market, are provided by the system operator.

An important condition for the functioning of the electricity market is the required availability of the related grid infrastructure. In turn, the capacity of electric grids is one of the factors determining the level of competition in the energy market, which should be considered as a system limitation.

In addition, the electricity market does not make it physically possible to enforce a product supply contract. In addition, financial derivatives for electricity are widely used in the world, which is also associated with the emergence of additional services markets. Thus, the electricity market is a complex system, provided by a large number of ancillary markets, which are usually called submarkets. Market power may include a large number of submarkets, the composition of which, together with the direct participants of the electricity market determines its architecture.

\subsection{Features of the Russian electricity market}

The main objective of the reform of the Russian electricity market was the creation of competition by separating the natural monopoly functions (power transmission, operational dispatch control) and potentially competitive functions (production and distribution of electric power, repair and service), and creation instead of vertically integrated companies, performing all these functions, of organizations specializing in certain types of activities.

The effective Russian electricity market has two tiers: wholesale and retail. It should be noted that the nature of economic relations arising in the sector differs significantly depending on whether they are formed as part of the wholesale or retail electricity market. In the wholesale market, electricity suppliers (generating companies, importers of electricity) sell to customers (guaranteeing suppliers, sales companies, large consumers, exporters of electricity) two commodities-electricity and capacity.

The first (transitional) stage of the wholesale electricity market (WEM) operation ended in December 2010, and starting from January 1, 2011, this market has been working in under the new model. The need to change for the new model of the wholesale market was particularly determined by the fact that the earlier model of the market did not stimulate to enter into long-term contracts (like in the Scandinavian countries, for example); the direction and amounts of capacity changes by energy producers were not fully focused on achieving reliability and stability of energy supply. In addition, there were processes of consolidation of energy assets, which is contrary to the principles of market competition and necessitates government intervention in pricing, including the "manual control." The new electricity market model involves the implementation of electricity trade in the context of the three sectors: long-term bilateral contracts; the dayahead market (DAM); the balancing market (BM) (Gitel'man and Ratnikov, 2009).

Another feature of the Russian market is the structuring of the wholesale market into two "price" zones-the first one includes European Russia and the Urals, the second-Siberia, while in the USA, there are much more zones. The Far East, Komi Republic, Kaliningrad, and Arkhangelsk regions belong to the so-called "non-price areas," because in these regions due to the relative isolation from the unified energy system of Russia, it is currently impossible to organize a competitive market. In addition, 28 zones of free power transfer were singled out, including: 22 in the first price zone, 6 in the second. Characteristics of the wholesale market price zones are shown in Table 1.

Table 1. Characteristics of the wholesale market price zones

\begin{tabular}{|l|l|l|l|}
\hline Indicator & European part & Siberia & Non-price zones \\
\hline $\begin{array}{l}\text { Installed } \\
\text { capacity }\end{array}$ & $\begin{array}{l}72-75 \% \text { of the total value, and is fairly } \\
\text { evenly distributed across the territory }\end{array}$ & about $20 \%$ of the total value & less than $10 \%$ of the installed capacity \\
\hline $\begin{array}{l}\text { Grid } \\
\text { infrastructure }\end{array}$ & a developed grid infrastructure & $\begin{array}{l}\text { relatively weak links between the } \\
\text { European region and the Far East }\end{array}$ & $\begin{array}{l}\text { several large power plants and a weakly } \\
\text { developed grid on a large territory }\end{array}$ \\
\hline
\end{tabular}


The first and second price zones are characterized by a large number of suppliers and purchasers of electricity, a developed grid infrastructure that allows the competitive electricity market to function. In the non-price zones, the structure of generation and distribution of electricity does not allow to organize full-fledged market relations. All free power transfer zones of the wholesale electricity market are characterized by a high concentration of manufacturers.

By the level of market concentration (based on the volume of production and the amount of the equipment installed capacity), the wholesale market of electric energy and capacity within the geographic boundaries of the first price zone is moderately concentrated and within the geographic boundaries of the second price zone, as well as within the boundaries of the free power transfer zones is highly concentrated. Reform of the electric power industry has led to an increase in the number of independent members of the wholesale market of electric energy (capacity), and reduction of the level of concentration on it. Thus, only for the first half of the transitional period of the Russian market operation, as a result of the reorganization of RAO "UES of Russia", the market concentration indicators changed significantly: there was a 3-fold increase in the number of participants of the wholesale market of electric power (capacity) in the first price zone, a 2-fold increase in the second; the concentration ratios (CR3) improved; the Herfindahl Hirschman index (HHI) used to assess the competitive environment reduced from the values above 5,300 to 1,147-2,400 (Chukhlantsev, 2010).

In addition to the geographical, there is a structural division of the wholesale electricity market caused by the specificity of production and consumption of power: the inability to store significant amounts of electricity, the need to maintain a balance between production and consumption of electricity at any given moment.

\section{Discussion}

One of the advantages for the creation of a competitive electricity market in Russia is the availability of international experience in reforming the electric power industry. The world practice to date has developed various models of the energy market, with the market of each country being relatively unique. Depending on how to ensure the reliability of the power system, the following markets can be distinguished: a market without capacity turnover (e.g. the UK and Australian markets); a market with regulated capacity payments (e.g. Spain, South Korea, and South America), two-sided capacity market (American markets with vertically integrated companies); short-term and long-term centralized capacity markets that are used with limitations. The reforms in the UK and Scandinavian countries are the examples of successful reforming of the energy sector (Brovkina, 2010; Fereidoon, 2011).

In domestic electricity markets of the Scandinavian countries, national producers, suppliers, and consumers of electrical energy operate. For example, in the electricity market of Finland, there are about 120 producers of electric power; transmission of electrical energy is provided by the operator of the national grid, 10 regional grid operators and more than 100 distribution companies. In Norway, the producers of electrical energy are represented by the Stattkraft state company and large municipal companies, and the transmission of electricity in the country is provided by the state power grid company Statnett. In addition, end-users obtain electricity from about 220 regional suppliers. In Sweden, the production of electricity is carried out by several public and private generation companies, transmission of electricity is provided by the state power grid company Svenska Kraftnat. The Danish electricity market is also represented by power producers, regional suppliers, and end-users.

The architecture of the Russian electricity market has not yet been fully formed, which to some extent determines its immaturity, and requires additional measures aimed at creating conditions for the development and functioning of a competitive industry market. This is possible through the study of the positive and negative experiences of other countries, evaluation of the functioning of various models of markets and consequences for the economy, market participants and consumers.

The competitive environment of the electricity market is largely determined by the structure of generating capacities. In addition, the state of the industry requires measures to change the capacity of both generation and transmission of electricity. For the development of generation and grids, it is necessary to form mutually binding relationships between generating and grid companies for connection of a new generating facility to grids. The presence of such relationships allows a generating company to expect that by the time of completion of construction of a new generator, it will be able to transmit electricity to the grid. On the other hand, the grid company receives assurances that the investment in the creation of a scheme of power distribution will be justified. The key issue of contractual relations is the question of the level of connection charges. For a generating company, this question is important for the purpose of making an investment decision on the construction; and for a grid company-for the purpose of forming a long-term investment program. Thus, the question of payment for connection is important to ensure equal conditions of competition, to stimulate the emergence of "generators" at those points of the grid, which are the most suitable for the energy system as a whole, and requires further research. 


\section{Conclusion}

A reform of the electric power industry and formation of an electricity market pursued emergence of competition among producers, as one of the basic conditions for the normal operation of the wholesale electricity market is its competitiveness. However, the level of competition in the electricity market is largely dependent on the presence of restrictions in the choice of retail markets; differentiation of the product; choice of fuel resources and their suppliers.

Reform of the electric power industry in Russia based on the experience of other countries was carried out by the structural transformation of the industry; transformation of the electricity markets; improvement of the system and mechanisms of investment in the industry development; strengthening the role of the state in the management of electric power; improvement of the system of regulation and formation of tariffs for electric and heat energy; energy efficiency stimulation and energy demand management; improvement of the corporate governance system for electric power companies; formation of a system of regulatory support of reforming, functioning, and developing the industry; and other tools. At the same time, the creation of the electricity market in the country cannot be considered completed. Therefore, further research is needed in the area of the operation and development of the electricity market, the study of successful international experience in this field, which will allow working out administrative decisions to adjust the regulatory mechanisms and conditions of the electricity market operation.

\section{References}

Aiuev, B.I. (2008) Kontseptualnyie osnovy rynka moshchnosti [Conceptual bases of the market of power]. Elektricheskie stantsii Electrical station, 8, 4-6 [in Russian].

Andreev, V., Baronin, S., Savinov, I., \& Tolstyih, lu. (2013). Konkurentnye rynki optovoi i roznichnoi elektroenergii v Rossii [The competitive markets of the wholesale and retail electric power in Russia]. Moscow: Infra-M [in Russian].

Averch, H., \& Johnson, L. (1962). Behaviour of the Firm under Regulatory Constraint. American Economic Review, Vol. 52, 5.

Balandin, D.V. (2005). Struktura i osobennosti rynka elektroenergii: mezhstranovyi analiz (na primere riada stran - chlenov OESR) [Structure and features of the market of the electric power: the intercountry analysis (on the example of a number of member countries of OECD)]. Vestnik SPbGU - Bulletin of St.Petersburg State University, 3, 167-188 [in Russian].

Barinov, V.A. (2013). Perspektivy razvitiia elektroenergetiki Rossii na period do $2030 \mathrm{~g}$. [Prospects of development of power industry of Russia for the period till 2030]. Izdatelstvo INP RAN [in Russian]

Belyaev, L.S., \& Podkovalnikov, S.V. (2008). Rynok v elektroenergetike: Problemy razvitiia generiruiushchikh moshchnostei [The market in power industry: Problems of development of the generating capacities]. Novosibirsk: Nauka [in Russian].

Brovkina, Iu. (2010). Postavka elektroenergii na roznichnyi rynok v usloviiakh konkurentsii: zarubezhnyi opyt [Delivery of the electric power to the retail market in the conditions of the competition: foreign experience]. Energorynok - Power market, 1, 55-58 [in Russian].

Chukhlantsev, S.S. (2010). Upravlenie effektivnost'iu deiatelnosti energogeneriruiushchei kompanii v usloviiakh institutsinalnikh preobrazovanii [Management of efficiency of activity of the power generation company in the conditions of institutional transformations]. Candidate's thesis. Tyumen [in Russian].

Domah, P., \& Pollitt, M.G. (2001). The Restructuring and Privatisation of Electricity Distribution and Supply Businesses in England and Wales: A Social Cost-Benefit Analysis. Fiscal Studies. Vol. 22, 1, 107-146.

Eremin, V. (2012). Mezhdunarodnyi opyt organizatsii rynkov moshchnosti [International experience of the organization of the markets of power]. bigpowernews.ru. Retrieved from http://www.bigpowernews.ru/research/document38893.phtml [in Russian]

Fereidoon, P.S. (2011). Competitive Electricity Markets: Design, Implementation, Performance. Elsevier.

Gitelman, L.D. (2014). Management education for a sustainable electric power industry in the $21^{\text {st }}$ century. Wit Transactions on Ecology and the Environment, 2, 1197-1213.

Gitelman, L.D. (2014). Russian power sector reform: lessons for developing countries. Wit Transactions on Ecology and the Environment, 1, 19-26.

Gitelman, L. \& Ratnikov, B. (2009) Reforma elektroenergetiki: otsenka effektivnosti i korrektirovka kursa [Reform of power industry: assessment of efficiency and correction of a course] Energoryinok - Power market, 1, 10-14 [in Russian]

Gitelman, L.D., \& Ratnikov, B.E. (2006). Energeticheskii biznes [Energy business]. Moscow: Delo [in Russian]

Harris, C. (2011). Electricity Markets: Pricing, Structures and Economics. John Wiley \& Sons.

Hunt, S., \& Shuttleworth, G. (1996). Competition and Choice in Electricity. Chichester: John Wiley \& Sons.

Kleyner, V.G. (1999). Mezhdunarodnyi opyt restrukturizatsii elektroenergetiki: vyvody i nabliudeniia dlia Rossii [International experience of restructuring of power industry: conclusions and supervision for Russia]. Moscow: Delo Ltd [in Russian].

Kuznetsov, Iu.V., Lebedev, G.V., \& Lvin, B.M. (1999). Kontseptsiia razvitiia energetiki v Rossiiskoi Federatsii [The concept of development of power in the Russian Federation]. Moscow: Izdatelstvo MGTU [in Russian].

Makarov, A.A. (2007). Elektroenergetika Rossii v period do 2030 goda: kontury zhelaemogo budushchego [Power industry of Russia during the period till 2030: contours of the desirable future]. Moscow: INEI RAN [in Russian].

Pérez-Arriaga, I.J. (2014). Regulation of the Power Sector (Power Systems). Springer Science \& Business Media. 
Trachuk, A.V. (2009). Model rynka moshchnosti s konkurentsiei po polnym zatratam [Power market model with the competition on full expenses]. Rossiiskoe predprinimatel'stvo - Russian business, 12, 88-93 [in Russian]

Tukenov, A.A. (2013). Integratsiia rynkov elektroenergii Evropy. Etapy, mekhanizmy, dostignutyi progress [Integration of the markets of the electric power of Europe. Stages, mechanisms, the made progress]. Moscow: Izdatelstvo IKAR [in Russian].

Tukenov, A.A. (2007). Rynok elektroenergii: ot monopolii k konkurentsii [Market of the electric power: from monopoly to the competition]. Moscow: Energoatomizdat [in Russian].

VanDoren, P. (1998). The Deregulation of the Electricity Industry. A Primer. Cato Policy Analysis. libertarium.ru. Retrieved from http://www.cato.org/pubs/pas/pa-320es.html. 